\title{
APROXIMACIÓN AL EFECTO DE LA TRASHUMANCIA EN EL DESEMPEÑO DE LOS SISTEMAS DE PRODUCCIÓN APÍCOLA CARACTERÍSTICOS DE LA ZONA CENTRAL DE LA PROVINCIA DE SANTA FE: CAMPAÑA 2009/10
}

\author{
Ulmer, J. ${ }^{2} ; \quad$ Travadelo, M. ${ }^{2} ;$ Caporgno, J. ${ }^{3}$ \& Castignani, H. ${ }^{4}$
}

\begin{abstract}
RESUMEN
El objetivo fue analizar el comportamiento de los sistemas de producción apícolas característicos del centro de Santa Fe, para obtener indicadores físicos y económicos que reflejen la dotación de recursos aplicados, los resultados económicos y la eficiencia de los procesos productivos, que permitan un acercamiento al efecto que la aplicación de trashumancia tiene sobre los mismos. Para ello se realizó un estudio de múltiples casos. La selección de las empresas se realizó a partir de informantes calificados. Se encuestaron 18 empresas apícolas, de las cuales se recabó información técnico-económica correspondiente al período 2009/10, siendo procesada con el modelo de Gestión Apícola de INTA. Esto permitió realizar un análisis horizontal aplicando el método comparativo, discriminándose en función de la presencia-ausencia de trashumancia. El estudio orienta sobre las principales variables que intervienen en el desempeño de esta tecnología en los sistemas de producción apícolas del centro de Santa Fe. Si bien las condiciones climáticas afectaron los resultados, se observó cierta tendencia de su uso en estratos con mayor número de colmenas, sea orientado a lograr una mayor eficiencia en los procesos productivos o como estrategia de crecimiento en la actividad.

Palabras clave: apicultura, trashumancia, sistemas apícolas, provincia Santa Fe.
\end{abstract}

1.-Facultad de Ciencias Agrarias, Universidad Nacional del Litoral - CAI+D 2009: Las agrupaciones de colaboración empresaria en el sector apícola de las Provincias de Santa Fe y Este de Córdoba: factores que afectan el desempeño en su vinculación con los mercados.

2.- Facultad de Ciencias Agrarias (UNL). Kreder 2805. (3080) Esperanza, provincia de Santa Fe.

Tel. (03496) 426400. Email: julmer@fca.unl.edu.ar.

3.- Instituto Nacional de Tecnología Agropecuaria - Agencia de Extensión Rural Ceres. Ceres, provincia de Santa Fe.

4.- Instituto Nacional de Tecnología Agropecuaria - Estación Experimental Rafaela. Rafaela, provincia de Santa Fe.

Manuscrito recibido el 20 de abril de 2012 y aceptado para su publicación el 22 de octubre de 2012. 


\section{SUMMARY}

\section{Approach to the effect of transhumance in the performance of characte- ristic beekeeping production systems of the central area of the province of Santa Fe: 2009/10 season.}

The purpose was to analyze the behavior of characteristic beekeeping production systems of the central region of Santa Fe (Argentina), for physical and economic indicators that reflect the allocation of resources applied, economic performance and efficiency of production processes, allowing an approach to effect that the application of transhumance has thereon. To do this we conducted a multiple case study. Primary data were collected through the use of a questionnaire in 18 enterprises, selected by specialized informants. The economic and technical information for the period 2009/10 was processed with the Bee Management Model of the INTA and allowed a horizontal analysis using the method of comparative analysis. Presence-absence of transhumance was used as a discriminated variable. The study focuses on the main variables involved in the performance of this technology in beekeeping production systems from downtown Santa Fe. Weather conditions for the campaign adversely affected the results of the activity. Migration is made by beekeepers that have the highest number of hives, probably looking for greater efficiency in production processes or as a growth strategy in the activity.

Key words: beekeeping, transhumance, beekeeping systems, Santa Fe province.

\section{INTRODUCCIÓN}

La apicultura en Argentina es una actividad que se basa mayormente en pequeños productores muy atomizados, que generan en conjunto divisas cercanas a los 80 millones de dólares anuales, cuya producción anual es de 80000 a 90000 t de miel destinada mayormente al mercado internacional (Ministerio de la Producción, 2010).

La principal zona apícola de Argentina, coincide con la región pampeana, en cuyas praderas se asientan más del $70 \%$ de las colmenas del país. El rendimiento anual promedio de miel es alrededor de $30 \mathrm{~kg} /$ colmena (Consejo Federal de Inversiones, 2008). La producción de miel toma en cada región características diferenciales debido fundamentalmente a variaciones en clima y flora. Estas variaciones determinan diferentes épocas de cosecha, volúmenes de producción y calidad de miel (Rivera Rúa \& Zuliani, 2000).

En la Provincia de Santa Fe, según datos del Registro Nacional de Productores Apícolas (RENAPA), el número total de productores registrados en el año 2008 era de 3735 , distribuidos de manera muy dispersa con un total de 435935 colmenas, siendo el volumen de producción de miel cada vez más significativo, representando entre el 14 y el $16 \%$ del total nacional (Ministerio de la Producción, 2010). Por su parte, los departamentos que componen el ámbito de estudio ubicados en la zona central de la provincia de Santa Fe (San Cristóbal, Castellanos y Las Colonias), comprenden un 43,7\% de las colmenas de la provincia (IPEC, 2007), siendo la apicultura una actividad relevante en la misma.

A pesar de ser Santa Fe una gran productora de miel, muestra regiones donde 